\title{
PERENCANAAN PRODUKSI DAN PENGENDALIAN PERSEDIAAN BAHAN BAKU DI PT. JAKARANA TAMA MEDAN
}

\author{
Muhammad Zakaria, Sri Meutia dan Ayrianti Melinda Pane \\ Jurusan Teknik Industri, Fakultas Teknik, Universitas Malikussaleh, Aceh, Indonesia \\ ${ }^{*}$ Corresponding Author: irmuhammad@unimal.ac.id
}

\begin{abstract}
Abstrak - PT. Jakarana Tama merupakan salah satu perusahaan yang bergerak dibidang industri makanan cepat saji dengan produk akhir berupa mie instan. Produk mie instan ini diproduksi dengan merk gaga mie. Perusahaan ini dalam kegiatan produksinya sering mengalami kesulitan dalam menentukan jumlah produksi yang optimal disebabkan karena besarnya permintaan produk yang bersifat fluktuatif dan persediaan bahan baku yang tidak terkendali akibatnya sering terjadi kelebihan bahan baku. Pada bulan-bulan tertentu kapasitas produksi lebih besar dari permintaan pasar yang mengakibatkan terjadi penumpukan barang dan besarnya biaya penyimpanan yang dikeluarkan sehingga perusahaan tidak memperoleh keuntungan yang optimal, maka diperlukan perencanaan produksi yang optimal dengan metode program dinamis dan pengendalian persediaan dengan metode EOQ (Economic Order Quantity). Penelitian ini bertujuan untuk mengetahui jumlah persediaan bahan baku yang optimal agar menghasilkan rencana produksi yang tepat untuk memaksimumkan keuntungan dan dapat menunjang kelancaran operasional perusahaan. Hasil perhitungan biaya produksi dengan menggunakan perencanaan diperoleh biaya sebesar Rp. 67.589.432.234 dan biaya produksi tanpa perencanaan sebesar Rp. 74.575 .569 .472 selama satu tahun. Persentase tingkat efisiensi penghematan biaya yang diperoleh oleh pihak perusahaan jika perusahaan menerapkan sistem perencanaan produksi maka diperoleh penghematan sebesar 9,37\%.Dengan jumlah pemesanan yang optimal pada bahan baku tepung terigu adalah 231.842 karung (frekuensi pemesanan 2 kali per tahun) dan jumlah pemesanan yang optimal pada bahan baku tepung tapioka adalah 6.570 karung (frekuensi pemesanan 2 kali per tahun).
\end{abstract}

Kata Kunci: Program Dinamis, Economic Order Quantity

\section{Pendahuluan}

Produksi merupakan kegiatan inti dari sebuah perusahaan untuk menghasilkan produk yang berkualitas dan sesuai dengan keinginan konsumen. Untuk melakukan kegiatan produksi, bahan baku merupakan unsur yang paling penting dalam menunjang proses produksi. Dengan proses bahan baku yang diolah menjadi barang jadi maka perusahaan akan memperoleh suatu produk yang siap untuk diperjualbelikan kepada konsumen. Dalam menjamin kelancaran proses produksi, perusahaan perlu melakukan pengelolaan persediaan bahan baku secara terkendali [1].

Pengendalian persediaan memiliki peran yang sangat penting dalam memperkirakan produk yang harus diproduksi untuk memenuhi permintaan pasar dan mempengaruhi kelancaran proses produksi pada perusahaan tersebut. Apabila terjadi kekurangan persediaan produk (out of stock) pada perusahaan dapat berakibat akan kehilangan kesempatan untuk menjual produk (lost sales). Sebaliknya, apabila terjadi kelebihan persediaan produk (over stock) yang cukup besar berakibat biaya inventory akan meningkat [2].

PT. Jakarana Tama merupakan salah satu perusahaan yang bergerak dibidang industri makanan cepat saji dengan produk akhir berupa mie instan. Produk mie instan ini diproduksi dengan merk gaga mie. Perusahaan ini dalam kegiatan produksinya sering mengalami kesulitan dalam menentukan jumlah 
produksi yang optimal disebabkan karena besarnya permintaan produk yang bersifat fluktuatif dan persediaan bahan baku yang tidak terkendali akibatnya sering terjadi kelebihan bahan baku. Pada bulan-bulan tertentu kapasitas produksi lebih besar dari permintaan pasar yang mengakibatkan terjadi penumpukan barang digudang dan besarnya biaya penyimpanan yang dikeluarkan sehingga perusahaan tidak memperoleh keuntungan yang optimal.

Penelitian ini dilakukan untuk mendapatkan sebuah model yang dapat digunakan perusahaan dalam melakukan perencanaan produksi dan pengendalian persediaan bahan baku yang bertujuan menghasilkan rencana produksi yang tepat untuk memaksimumkan keuntungan. Dalam hal ini penulis menggunakan salah satu metode yang dapat mengoptimalkan perencanaan produksi yaitu program dinamik yang merupakan suatu teknik matematis dalam menentukan kombinasi keputusan yang optimal dengan cara pendekatan secara umum dan menggunakan metode EOQ (Economic Order Quantity) dalam mengendalikan persediaan bahan baku.

Adapun tujuan yang ingin dicapai dalam penelitian ini adalah sebagai berikut:

1. Untuk mengetahui perencanaan produksi dengan menggunakan pemrograman dinamis sehingga dapat meminimumkan biaya produksi.

2. Untuk mengetahui jumlah persediaan bahan baku yang optimal agar dapat menunjang kelancaran operasional perusahaan.

\section{Tinjauan Pustaka}

\section{Perencanaan Produksi}

Perencanaan produksi merupakan suatu kegiatan mengenai produk apa yang sesuai dengan yang ditetapkan, dengan penentuan berapa banyak yang diproduksi, sumber daya apa yang dibutuhkan dan kapan akan diproduksi oleh perusahaan dalam satu periode yang akan datang. Dalam penyusunan perencanaan produksi, perlu dilakukan adanya optimasi produksi sehingga akan dapat dicapai tingkat biaya yang paling rendah untuk pelaksanaan proses produksi tersebut [3] [4].

\section{Sistem Perencanaan dan Pengendalian Produksi}

Sistem perencanaan dan pengendalian produksi terdiri dari beberapa sub sistem yang dirancang untuk tercapainya kepuasan pelanggan dan tingginya tingkat utilitas penggunaan sumber daya produksi [5].

Perencanaan produksi dimulai dengan meramalkan permintaan secara tepat sebagai input utamanya. Perencanaan jangka panjang membantu manajer puncak dalam isu strategi dan penentuan kapasitas. Perencanaan jangka menengah dimulai sejak keputusan kapasitas jangka panjang dibuat. Perencanaan jangka pendek dibuat untuk paling lama tiga bulan ke depan [6].

\section{Pengendalian Persediaan}

Pengendalian adalah tindakan yang sangat penting dalam menghitung berapa jumlah optimal tingkat persediaan yang diharuskan, serta kapan saatnya mulai mengadakan pemesanan kembali [7].

Persediaan adalah sejumlah barang atau bahan yang dimiliki oleh suatu perusahaan yang bertujuan untuk di jual maupun diolah kembali [8].

\section{Peramalan}

Dalam kegiatan produksi, peramalan dilakukan untuk menentukan jumlah permintaan terhadap suatu produk dan merupakan langkah awal dari proses perencanaan dan pengendalian produksi [9] [10].

Prosedur umum yang digunakan dalam peramalan secara kuantitatif adalah [11]:

1. Definisikan tujuan peramalan.

2. Pembuatan diagram pencar.

3. Pilih metode peramalan yang dianggap sesuai.

4. Hitung parameter - parameter fungsi peramalan.

5. Hitung kesalahan setiap metode peramalan.

6. Pilih metode yang terbaik

7. Lakukan verifikasi peramalan.

\section{Metode Pengendalian Secara Statistik (Statistical Inventory Control)}

Metode ini berguna untuk mengoptimalkan hal-hal berikut ini [12]:

1. Jumlah ukuran pemesanan dinamis (EOQ)

EOQ adalah salah satu metode yang digunakan untuk mengendalikan persediaan. Menurut Wiratna Sujarweni (2015) menyatakan Economic Order Quantity (EOQ) adalah jumlah persediaan yang harus dipesan pada satu saat dengan tujuan untuk mengurangi biaya tahunan. Rumus EOQ adalah $E O Q=\sqrt{\frac{2 D S}{H}}$

2. Jumlah Cadangan Pengaman (Safety Stock) yang Diperlukan

Persediaan pengaman (safety stock) adalah persediaan tambahan yang diadakan untuk melindungi atau menjaga kemungkinan terjadinya kekurangan bahan (stock out), (Freddy Rangkuti, 1995).Rumus umum menghitung safety stock adalah $S S=Z \times \sigma$

3. Titik pemesanan kembali (Reorder Point)

Reorder point adalah suatu titik atau batas dari jumlah persediaan yang ada pada suatu saat di mana pemesanan harus diadakan kembali, (Sofjan Assauri, 2004). Untuk menentukan ROP digunakan rumus $R O P=(D \times L)+S S$ 


\section{Optimasi}

Optimasi adalah suatu pendekatan normatif untuk mengidentifikasikan penyelesaian terbaik dalam pengambilan keputusan dari suatu permasalahan. Penyelesaian permasalahan dalam optimisasi ditujukan untuk memperoleh titik maksimum atau titik minimum dari fungsi yang dioptimumkan [13] [14].

\section{Program Dinamis}

Pemrograman dinamis adalah suatu teknik matematis yang digunakan dalam menentukan kombinasi keputusan yang optimal. Ini dikembangkan oleh seorang ilmuwan bernama Richard Bellman pada tahun 1957 yang mengatakan "Suatu kebijakan optimal mempunyai sifat bahwa apapun keadaan dan keputusan awal, keputusan berikutnya harus membentuk suatu kebijakan optimal dengan mempertimbangkan keadaan dari hasil keputusan pertama".

Konsep-konsep dasar dalam dynamic programming antara lain [15]:

1. Dekomposisi

Persoalan program dinamis dapat dipecah menjadi tahapan yang lebih kecil dan berurutan.

2. Status

Status adalah keadaan awal (Sn) dan keadaan akhir (Sn-1) pada setiap tahap, dimana pada tahap tersebut keputusan dibuat (Xn).

3. Variabel Keputusan dan Hasil

Keputusan yang dibuat pada setiap tahap (Xn) merupakan keputusan yang berorientasi kepada hasil yang diakibatkannya, tingkat minimal atau maksimal.

4. Fungsi Transisi

Fungsi transisi menjelaskan secara pasti bagaimana tahap-tahap saling berhubungan.

5. Optimasi Stage

Optimasi stage dalam program dinamis adalah menentukan keputusan optimal pada setiap tahap dari berbagai kemungkinan nilai status inputnya.

6. Fungsi rekursif

Fungsi rekursif adalah nilai sebuah variabel pada fungsi itu merupakan nilai kumulatif dari nilai variabel tersebut pada tahap sebelumnya. Secara umum fungsi rekursif berbentuk:

$f_{n}{ }^{*}\left(S_{n}\right)=\operatorname{Max} / \operatorname{Min}\left\{f_{n}\left(s_{n}, x_{n}\right)\right\}$

Adapun proses perhitungan dynamic programming dapat dilihat pada Tabel 1.

Tabel 1. Perhitungan Perencanaan Produksi dengan Menggunakan Dynamic Programming

\begin{tabular}{|c|c|c|c|c|c|c|c|}
\hline \multicolumn{7}{|c|}{ Stage n } \\
\hline$X_{n}$ & $f_{n}{ }^{*}\left(I_{n}\right)=C_{n}\left(X_{n}, I_{n}\right)+f^{*}{ }_{n-1}\left(I_{n}+X_{n}-S_{n}\right)$ & $f_{n}{ }^{*}\left(I_{n}\right)$ & $X_{n}{ }^{*}$ \\
\cline { 2 - 7 }$I_{n}$ & & & & & & & \\
\hline$I_{n}$ & & & & & & & \\
\hline$I_{n}$ & & & & & & & \\
\hline
\end{tabular}

Prosedur pemecahan dalam program dinamik dilakukan secara rekursif. Ini berarti bahwa setiap kali mengambil keputusan harus memperhatikan keadaan yang dihasilkan oleh keputusan sebelumnya [16].

\section{Metodelogi Penelitian}

Adapun skema yang dilakukan dalam melakukan penelitian yaitu sebagai berikut: (lihat Gambar 1).

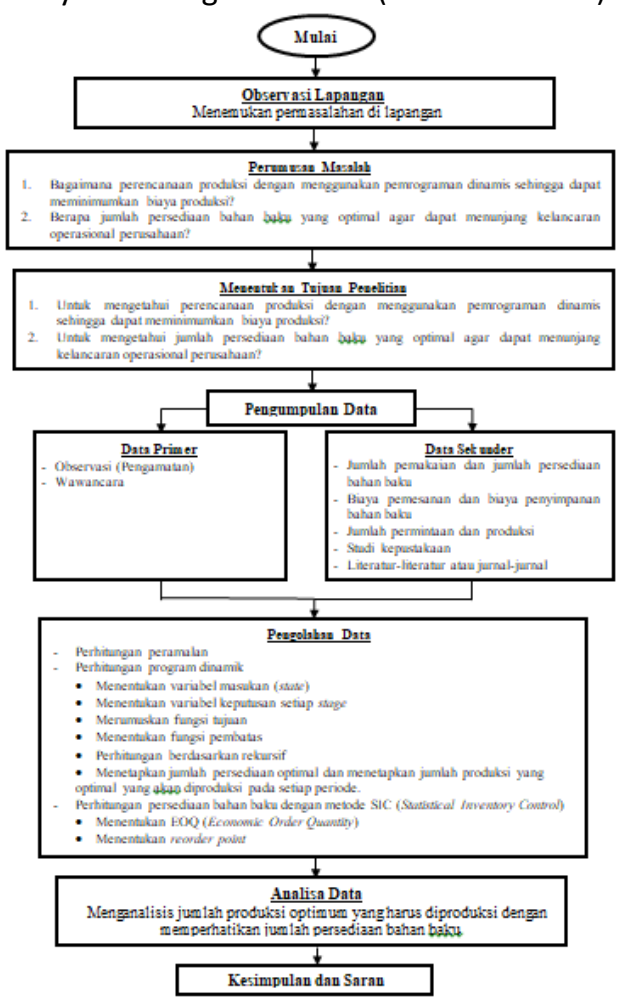

Gambar 1. Skema Metodelogi Penelitian

\section{Hasil Penelitian dan Pembahasan}

Untuk menyelesaikan permasalahan perencanaan produksi yang terjadi di PT. Jakarana Tama dengan menggunakan metode program dinamik, diperlukan data jumlah penjualan produk mie instan gaga, data hari kerja, data supply capacity, data biaya bahan, biaya listrik, dan biaya tenaga kerja.

Data jumlah penjualan produk mie instan gaga pada tahun 2019 dapat dilihat pada pada Tabel 2.

Tabel 2. Data Jumlah Penjualan Mie Instan Gaga Tahun 2019

\begin{tabular}{|c|l|c|}
\hline No. & Bulan & Penjualan (Karton) \\
\hline 1 & Januari & 216.155 \\
\hline 2 & Februari & 212.854 \\
\hline 3 & Maret & 219.366 \\
\hline 4 & April & 219.458 \\
\hline 5 & Mei & 196.342 \\
\hline 6 & Juni & 193.041 \\
\hline 7 & Juli & 210.553 \\
\hline 8 & Agustus & 206.229 \\
\hline
\end{tabular}




\begin{tabular}{|c|l|c|}
\hline 9 & September & 202.947 \\
\hline 10 & Oktober & 199.646 \\
\hline 11 & November & 226.063 \\
\hline 12 & Desember & 222.790 \\
\hline \multicolumn{2}{|c|}{ Jumlah } & $\mathbf{2 . 5 2 5 . 4 4 4}$ \\
\hline
\end{tabular}

Data jumlah hari kerja dan jam kerja tersedia pada bulan tahun 2019 dapat dilihat pada Tabel 3.

Tabel 3. Jumlah Hari Kerja Dan Jam Kerja Tersedia Tahun 2019

\begin{tabular}{|c|l|c|c|}
\hline No. & Bulan & $\begin{array}{c}\text { Jumlah } \\
\text { (Hari) }\end{array}$ & $\begin{array}{c}\text { Jumlah Waku } \\
\text { Kerja (Jam) }\end{array}$ \\
\hline 1 & Januari & 21 & 168 \\
\hline 2 & Februari & 21 & 168 \\
\hline 3 & Maret & 22 & 176 \\
\hline 4 & April & 23 & 184 \\
\hline 5 & Mei & 24 & 192 \\
\hline 6 & Juni & 24 & 192 \\
\hline 7 & Juli & 25 & 200 \\
\hline 8 & Agustus & 26 & 208 \\
\hline 9 & September & 26 & 208 \\
\hline 10 & Oktober & 26 & 208 \\
\hline 11 & November & 25 & 200 \\
\hline 12 & Desember & 26 & 208 \\
\hline \multicolumn{2}{|c|}{ Total } & $\mathbf{2 8 9}$ & $\mathbf{2 . 3 1 2}$ \\
\hline
\end{tabular}

Rekapitulasi perhitungan kapasitas tersedia pada tahun 2019 dapat dilihat pada Tabel 4.

Tabel 4. Rekapitulasi Kapasitas Tersedia Mie Instan Gaga Tahun 2019

\begin{tabular}{|c|l|c|}
\hline No. & \multicolumn{1}{|c|}{ Bulan } & Kapasitas Tersedia (Karton) \\
\hline 1 & Januari & 263.760 \\
\hline 2 & Februari & 263.760 \\
\hline 3 & Maret & 276.320 \\
\hline 4 & April & 288.880 \\
\hline 5 & Mei & 301.440 \\
\hline 6 & Juni & 301.440 \\
\hline 7 & Juli & 314.000 \\
\hline 8 & Agustus & 326.560 \\
\hline 9 & September & 326.560 \\
\hline 10 & Oktober & 326.560 \\
\hline 11 & November & 392.500 \\
\hline 12 & Desember & 408.200 \\
\hline \multicolumn{2}{|c|}{ Jumlah } & 4.657 .856 \\
\hline
\end{tabular}

Data biaya bahan, biaya listrik, dan biaya tenaga kerja pada tahun 2019 dapat dilihat pada Tabel 5. Dari Tabel 5 diperoleh data biaya bahan, biaya listrik, dan biaya tenaga kerja untuk memproduksi 4.657 .856 karton mie instan adalah sebesar Rp. 74.575.569.472 sehingga dapat dikatakan bahwa biaya bahan baku, biaya listrik, dan biaya tenaga kerja untuk pembuatan satu karton mie instan gaga adalah 74.575.569.472/ 4.657.856 = Rp. 18.587. Diketahui bahwa persentase biaya simpan adalah $2 \%$ dari harga satu karton mie instan gaga maka biaya simpan per karton $=$ Rp. $18.587 \times 2 \%=$ Rp. 372 .

Tabel 5. Data Biaya Bahan, Biaya Listrik, Dan Biaya Tenaga Kerja Tahun 2019

\begin{tabular}{|l|c|c|c|c|}
\hline \multicolumn{1}{|c|}{ Bulan } & $\begin{array}{c}\text { Biaya } \\
\text { Bahan } \\
\text { (Milyaran } \\
\text { Rupiah) }\end{array}$ & $\begin{array}{c}\text { Biaya } \\
\text { Listrik } \\
\text { (Jutaan } \\
\text { Rupiah) }\end{array}$ & $\begin{array}{c}\text { Biaya Tenaga } \\
\text { Kerja } \\
\text { (Milyaran } \\
\text { Rupiah) }\end{array}$ & $\begin{array}{c}\text { Total } \\
\text { Biaya } \\
\text { (Milyaran } \\
\text { Rupiah) }\end{array}$ \\
\hline Januari & $2.378,8$ & 48,8 & $3.884,5$ & $6.312,1$ \\
\hline Februari & $2.104,5$ & 48,1 & $3.574,5$ & $5.727,1$ \\
\hline Maret & $2.318,7$ & 48,8 & $3.944,5$ & $6.312,1$ \\
\hline April & $2.329,2$ & 48,8 & $3.641,5$ & $6.019,6$ \\
\hline Mei & $2.462,5$ & 48,1 & $3.801,4$ & $6.312,1$ \\
\hline Juni & $2.204,1$ & 48,6 & $3.189,4$ & $5.142,1$ \\
\hline Juli & $2.871,2$ & 48,9 & $3.684,5$ & $6.604,6$ \\
\hline Agustus & $3.078,8$ & 48,2 & $3.184,5$ & $6.312,1$ \\
\hline September & $2.679,3$ & 48 & $3.584,7$ & $6.312,1$ \\
\hline Oktober & $2.942,8$ & 48,3 & $3.613,4$ & $6.604,6$ \\
\hline November & $2.545,2$ & 48,1 & $3.718,4$ & $6.312,1$ \\
\hline Desember & $2.971,9$ & 48,1 & $3.584,5$ & $6.604,6$ \\
\hline Total & $\mathbf{3 0 . 8 8 7 , 5}$ & $\mathbf{5 8 1 , 8}$ & $\mathbf{4 3 . 1 0 6 , 1}$ & $\mathbf{7 4 . 5 7 5 , 5}$ \\
\hline
\end{tabular}

\section{Peramalan}

Hasil peramalan berdasarkan permintaan mie instan gaga tahun 2019 untuk menentukan bahwa permintaan produk mie instan gaga pada tahun 2020 terlihat pada Tabel 6.

Tabel 6. Hasil Peramalan Tahun 2020

\begin{tabular}{|c|l|c|}
\hline No. & Periode & Jumlah Peramalan (Karton) \\
\hline 1 & Januari & 230.211 \\
\hline 2 & Februari & 239.201 \\
\hline 3 & Maret & 249.466 \\
\hline 4 & April & 261.006 \\
\hline 5 & Mei & 273.821 \\
\hline 6 & Juni & 287.911 \\
\hline 7 & Juli & 303.277 \\
\hline 8 & Agustus & 319.917 \\
\hline 9 & September & 337.832 \\
\hline 10 & Oktober & 357.023 \\
\hline 11 & November & 377.488 \\
\hline 12 & Desember & 399.229 \\
\hline & Total & $\mathbf{3 . 6 3 6 . 3 8 2}$ \\
\hline
\end{tabular}

Penentuan Jumlah Produksi dan Persediaan Optimal dengan Menggunakan Metode Dynamic Programming

Penyelesaian perencanaan produksi optimal dengan menggunakan metode program dinamik adalah sebagai berikut:

a. Dekomposisi: Persoalan perencanaan produksi bulan januari-desember dipecah-pecah menjadi submasalah atau tahapan (stage) yang lebih kecil dan berurutan. 
Tahapan yang dipecah terdiri dari stage bulan januari, februari, maret, april, mei, juni, juli, agustus, september, oktober, november, dan desember.

b. Menentukan variabel masukan/status (state) pada setiap tahapan.

Variabel masukan (state) pada setiap tahapan, merupakan input ketahap berikutnya. State pada bulan januari-desember dapat dilihat pada Tabel 7.

Tabel 7. Variabel Masukan (State) Periode JanuariDesember

\begin{tabular}{|c|l|c|c|}
\hline \multirow{2}{*}{ No. } & \multirow{2}{*}{ Bulan } & \multicolumn{2}{|c|}{ State (Input) (Karton) } \\
\cline { 3 - 4 } & & $\begin{array}{c}\text { Demand } \\
\text { Capacity }\end{array}$ & $\begin{array}{c}\text { Supply } \\
\text { Capacity }\end{array}$ \\
\hline 1 & Januari & 230.211 & 263.760 \\
\hline 2 & Februari & 239.201 & 263.760 \\
\hline 3 & Maret & 249.466 & 276.320 \\
\hline 4 & April & 261.006 & 288.880 \\
\hline 5 & Mei & 273.821 & 301.440 \\
\hline 6 & Juni & 287.911 & 301.440 \\
\hline 7 & Juli & 303.277 & 314.000 \\
\hline 8 & Agustus & 319.917 & 326.560 \\
\hline 9 & September & 337.832 & 326.560 \\
\hline 10 & Oktober & 357.023 & 326.560 \\
\hline 11 & November & 377.488 & 392.500 \\
\hline 12 & Desember & 399.229 & 408.200 \\
\hline
\end{tabular}

PT. Jakarana Tama memiliki 8 rak penyimpanan produk jadi dengan daya tampung sebesar 150.000 karton dengan rata-rata dan kumulatif jumlah persediaan setiap rak penyimpanan dapat dilihat pada Tabel 8.

Tabel 8. Hasil Perhitungan Rata-rata Dan Kumulatif Jumlah Persediaan Setiap Rak Penyimpanan

\begin{tabular}{|c|c|c|c|}
\hline No. & $\begin{array}{c}\text { Jumlah } \\
\text { Periode } \\
\text { Persediaan } \\
\text { Rak } \\
\text { Penyimpanan }\end{array}$ & $\begin{array}{c}\text { Rata-rata } \\
\text { Jumlah } \\
\text { Persediaan } \\
\text { Produk Jadi } \\
\text { (Karton) }\end{array}$ & $\begin{array}{c}\text { Kumulatif } \\
\text { Persediaan } \\
\text { Produk } \\
\text { Jadi } \\
\text { (Karton) }\end{array}$ \\
\hline 1 & 0 & 0 & 0 \\
\hline 2 & 1 & 18.750 & 18.750 \\
\hline 3 & 2 & 18.750 & 37.500 \\
\hline 4 & 3 & 18.750 & 56.250 \\
\hline 5 & 4 & 18.750 & 75.000 \\
\hline 6 & 5 & 18.750 & 93.750 \\
\hline 7 & 6 & 18.750 & 112.500 \\
\hline 8 & 7 & 18.750 & 131.250 \\
\hline 9 & 8 & 18.750 & 150.000 \\
\hline
\end{tabular}

\section{c. Menentukan variabel keputusan}

Menentukan alokasi jumlah produksi setiap bulan berdasarkan kenaikan jumlah persediaan sebesar 18.750 karton

d. Menetapkan fungus tujuan
$\operatorname{Min} C=\sum_{n=1}^{12} C\left(X_{n}, I_{n}\right)$

s.t $=8$, dengan mempertimbangkan jumlah rak penyimpanan. Fungsi rekursif untuk memberikan nilai pada fungsi tujuan setiap stage dengan persamaan:

$$
\begin{aligned}
& f_{n}\left(I_{n}\right)=\left\{C_{n}\left(X_{n}, I_{n}\right)+f^{*}{ }_{n-1}\left(I_{n}+X_{n}-S_{n}\right)\right\} \\
& \text { s.t }=S_{n}-\mathrm{i} \leq X_{n} \leq S_{n}
\end{aligned}
$$

$C_{n}\left(X_{n}, I_{n}\right)$ merupakan $\mathrm{c} X_{n}=$ total biaya produksi sebanyak $X_{n}$ unit dan $C I_{n}=$ total biaya untuk menyimpan In, dengan biaya variabel produksi per karton sebesar Rp. 18.587 dan biaya simpan sebesar Rp. 372 .

Perhitungan total biaya produksi berdasarkan jumlah produksi dan jumlah persediaan serta total biaya produksi pada bulan januari-desember dapat dilihat pada Lampiran 5. Rekapitulasi total biaya produksi bulan desember dapat dilihat pada Tabel 9.

Tabel 9. Rekapitulasi Total Biaya Produksi Bulan Desember

\begin{tabular}{|c|c|c|c|c|}
\hline (n) & $\begin{array}{c}\text { Jumlah } \\
\text { Produksi } \\
\text { (Karton) }\end{array}$ & $\begin{array}{c}\text { Biaya } \\
\text { Variabel } \\
\text { Produksi } \\
\text { (Milyaran } \\
\text { Rupiah) }\end{array}$ & $\begin{array}{c}\text { Biaya } \\
\text { Persediaan } \\
\text { (Jutaan } \\
\text { Rupiah) }\end{array}$ & $\begin{array}{c}\text { Total Biaya } \\
\text { Produksi } \\
\text { (Rp) }\end{array}$ \\
\hline 1 & 399.229 & $7.604,6$ & 0 & 7.420 .469 .423 \\
\hline 2 & 380.479 & $7.256,1$ & 6,9 & 7.078 .938 .173 \\
\hline 3 & 361.729 & $6.907,5$ & 13,9 & 6.737 .406 .923 \\
\hline 4 & 342.979 & 6.559 & 20,9 & 6.395 .875 .673 \\
\hline 5 & 324.229 & $6.210,5$ & 27,9 & 6.054 .344 .423 \\
\hline 6 & 305.479 & 5.862 & 34,8 & 5.712 .813 .173 \\
\hline 7 & 286.729 & $5.513,5$ & 41,8 & 5.371 .281 .923 \\
\hline 8 & 267.979 & 5.165 & 48,8 & 5.029 .750 .673 \\
\hline 9 & 249.229 & $4.816,5$ & 55,8 & 4.688 .219 .423 \\
\hline
\end{tabular}

Pada stage desember jumlah produksi maksimum yang harus diproduksi sebesar 399.229 karton dengan daya tampung gudang maksimum sebesar 150.000 karton. Untuk memenuhi permintaan konsumen, ada 9 periode persediaan yang dilakukan oleh perusahaan dengan mempertimbangkan banyaknya rak penyimpanan.

Rekapitulasi hasil perhitungan perencanaan produksi berdasarkan periode produksi pada bulan januari-desember maka dapat dilihat pada Tabel 10.

Tabel 10. Perencanaan Jumlah Produksi Optimal Mie Instan Gaga

\begin{tabular}{|c|l|c|}
\hline No. & Periode Produksi & Jumlah Produksi (Karton) \\
\hline 1 & Januari & 230.211 \\
\hline 2 & Februari & 239.201 \\
\hline 3 & Maret & 249.466 \\
\hline 4 & April & 261.006 \\
\hline 5 & Mei & 273.821 \\
\hline 6 & Juni & 287.911 \\
\hline 7 & Juli & 303.277 \\
\hline
\end{tabular}




\begin{tabular}{|c|l|c|}
\hline 8 & Agustus & 319.917 \\
\hline 9 & September & 337.832 \\
\hline 10 & Oktober & 357.023 \\
\hline 11 & November & 377.488 \\
\hline 12 & Desember & 399.229 \\
\hline
\end{tabular}

Jumlah produksi pada setiap bulan ditentukan oleh periode produksi yang memiliki jumlah persediaan yang paling minimum dengan melihat kapasitas produksi (supply capacity).

Setelah diketahui perencanaan produksi, selanjutnya menyelesaikan permasalahan pengendalian persediaan yang terjadi di PT. Jakarana Tama dengan menggunakan metode EOQ (Economic Order Quantity), diperlukan data pemakaian bahan baku, data biaya pemesanan, dan data penyimpanan bahan baku.

Data pemakaian bahan baku untuk pembuatan mie instan gaga pada tahun 2019 terdapat dalam Tabel 11.

Tabel 11. Data Pemakaian Bahan Baku Bulan Tahun 2019

\begin{tabular}{|l|c|c|}
\hline Bulan & $\begin{array}{c}\text { Tepung } \\
\text { Terigu } \\
\text { (Karung) }\end{array}$ & $\begin{array}{c}\text { Tepung } \\
\text { Tapioka } \\
\text { (Karung) }\end{array}$ \\
\hline Januari & 34.886 & 1.018 \\
\hline Februari & 31.865 & 930 \\
\hline Maret & 34.886 & 1.018 \\
\hline April & 33.376 & 974 \\
\hline Mei & 34.886 & 1.018 \\
\hline Juni & 28.844 & 841 \\
\hline Juli & 36.397 & 1.062 \\
\hline Agustus & 34.886 & 1.018 \\
\hline September & 34.886 & 1.018 \\
\hline Oktober & 36.397 & 1.062 \\
\hline November & 34.886 & 1.018 \\
\hline Desember & 36.397 & 1.062 \\
\hline Jumlah & $\mathbf{4 1 2 . 5 9 4}$ & $\mathbf{1 2 . 0 3 9}$ \\
\hline Rata-rata & $\mathbf{3 4 . 3 8 3}$ & $\mathbf{1 . 0 0 3}$ \\
\hline & & \\
\hline
\end{tabular}

Data biaya pemesanan bahan baku pada Tabel 12 .

Tabel 12. Harga Beli, Kuantitas, Frekuensi Pemesanan dan Biaya Pemesanan Bahan Baku

\begin{tabular}{|l|c|c|c|c|c|}
\hline $\begin{array}{c}\text { Jenis } \\
\text { Bahan } \\
\text { Baku }\end{array}$ & $\begin{array}{c}\text { Harga } \\
\text { Beli (Rp) }\end{array}$ & $\begin{array}{c}\text { Kuantitas } \\
\text { Pemesanan } \\
\text { (Karung) }\end{array}$ & $\begin{array}{c}\text { Frekuensi } \\
\text { (Kali) }\end{array}$ & $\begin{array}{c}\text { Biaya } \\
\text { Pemesanan } \\
\text { (Rp) }\end{array}$ & $\begin{array}{l}\text { Total Biaya } \\
\text { Pemesanan } \\
\text { (Karung) }\end{array}$ \\
\hline $\begin{array}{l}\text { Tepung } \\
\text { Terigu }\end{array}$ & 148.000 & 20.000 & 48 & 710.000 & 34.080 .000 \\
\hline $\begin{array}{l}\text { Tepung } \\
\text { Tapioka }\end{array}$ & 215.800 & 600 & 48 & 670.000 & 32.160 .000 \\
\hline
\end{tabular}

Data biaya penyimpanan bahan baku tepung dapat dilihat pada Tabel 13.

Tabel 13. Biaya Penyimpanan Bahan Baku

\begin{tabular}{|c|c|c|c|}
\hline $\begin{array}{c}\text { Jenis } \\
\text { Bahan } \\
\text { Baku } \\
\end{array}$ & $\begin{array}{l}\text { Persentase Biaya } \\
\text { Penyimpanan (\%) }\end{array}$ & $\begin{array}{c}\text { Biaya Listrik } \\
\text { dan Gudang } \\
\text { (Rp) }\end{array}$ & $\begin{array}{c}\text { Biaya } \\
\text { Penyimpanan } \\
\text { (Rp) }\end{array}$ \\
\hline $\begin{array}{l}\text { Tepung } \\
\text { Terigu }\end{array}$ & \multirow{2}{*}{12} & 37.500 .000 & 4.500 .000 \\
\hline $\begin{array}{l}\text { Tepung } \\
\text { Tapioka }\end{array}$ & & 37.500 .000 & 4.500 .000 \\
\hline
\end{tabular}

\section{Pengendalian Persediaan Bahan Baku Berdasarkan} Kondisi Aktual Perusahaan

Perhitungan total biaya persediaan berdasarkan kondisi aktual perusahaan selama tahun 2019 dapat dilihat pada Tabel 14.

Tabel 14. Perhitungan Total Biaya Persediaan Berdasarkan Kondisi Aktual Perusahaan Tahun 2019

\begin{tabular}{|l|c|c|c|}
\hline Jenis Bahan Baku & $\begin{array}{c}\text { Biaya } \\
\text { Pemesanan } \\
\text { (Rp) }\end{array}$ & $\begin{array}{c}\text { Biaya } \\
\text { Penyimpanan } \\
\text { (Rp) }\end{array}$ & $\begin{array}{c}\text { Total Biaya } \\
\text { Persediaan } \\
\text { (Rp) }\end{array}$ \\
\hline Tepung Terigu & 34.080 .000 & 4.500 .000 & 38.580 .000 \\
\hline Tepung Tapioka & 32.160 .000 & 4.500 .000 & 36.660 .000 \\
\hline
\end{tabular}

\section{Pengendalian Persediaan Bahan Baku Berdasarkan Metode EOQ \\ Perhitungan total biaya persediaan berdasarkan} metode EOQ dapat dilihat pada Tabel 15.

Tabel 15. Perhitungan Total Biaya Persediaan Berdasarkan Metode EOQ

\begin{tabular}{|c|c|c|c|c|c|}
\hline $\begin{array}{c}\text { Jenis } \\
\text { Bahan } \\
\text { Baku }\end{array}$ & $\begin{array}{c}\text { Kebutuhan } \\
\text { (Karung) }\end{array}$ & $\begin{array}{c}\text { Frekuensi } \\
\text { (Kali) }\end{array}$ & $\begin{array}{c}\text { Biaya } \\
\text { Pemesanan } \\
\text { (Rp) }\end{array}$ & $\begin{array}{c}\text { Biaya } \\
\text { Penyimpanan } \\
\text { /karung (Rp) }\end{array}$ & $\begin{array}{c}\text { Total Biaya } \\
\text { Pemesanan } \\
\text { (Karung) }\end{array}$ \\
\hline $\begin{array}{l}\text { Tepung } \\
\text { Terigu }\end{array}$ & 412.592 & 48 & 710.000 & 10,90 & 34.125 .527 \\
\hline $\begin{array}{l}\text { Tepung } \\
\text { Tapioka }\end{array}$ & 12.039 & 48 & 670.000 & 373,78 & 32.208 .475 \\
\hline
\end{tabular}

Perbandingan total biaya persediaan berdasarkan kebijakan perusahaan dan perhitungan menggunakan metode EOQ dapat dilihat pada Tabel 16.

Tabel 16. Perbandingan Total Biaya Persediaan Berdasarkan Kebijakan Perusahaan dan Berdasarkan Perhitungan Metode EOQ

\begin{tabular}{|l|c|c|c|}
\hline \multicolumn{1}{|c|}{ Bahan Baku } & $\begin{array}{c}\text { Kebijakan } \\
\text { Perusahaan (Rp) }\end{array}$ & $\begin{array}{c}\text { Metode } \\
\text { EOQ (Rp) }\end{array}$ & $\begin{array}{c}\text { Tingkat } \\
\text { Efisiensi } \\
\text { (\%) }\end{array}$ \\
\hline Tepung Terigu & 38.580 .000 & 34.125 .527 & \\
\cline { 1 - 3 } Tepung Tapioka & 36.660 .000 & 32.208 .475 & \\
\hline Total Biaya & 75.240 .000 & 66.334 .002 & 0,118 \\
\hline
\end{tabular}

\section{Penentuan Pemesanan Ekonomis Berdasarkan Metode EOQ}

Pemesanan bahan baku tepung terigu yang ekonomis adalah: 


$$
\begin{aligned}
E O Q & =\sqrt{\frac{2 D S}{H}} \\
E O Q & =\sqrt{\frac{2 \times 412.592 \times 710.000}{10,90}} \\
& =231.841,57 \text { karung } \approx 231.842 \text { karung }
\end{aligned}
$$

Dengan Frekuensi Pemesanan 2 kali/tahun

Besarnya persediaan pengaman yang harus ada adalah:

SS $=($ Pemakaian maksimum - rata-rata) lead time

$$
=(36.397-34.383) 3
$$$$
=6.042 \text { karung }
$$

Penentuan titik pemesanan ulang ketika persediaan bahan baku tepung terigu sebanyak:

$$
\begin{aligned}
\text { ROP } & =(d \times L)+S S \\
& =(1.146,09 \times 3)+6.042 \\
& =9.480,27 \approx 9.480 \text { karung }
\end{aligned}
$$

Pemesanan bahan baku tepung terigu yang ekonomis adalah:

$$
\begin{aligned}
E O Q & =\sqrt{\frac{2 D S}{H}} \\
E O Q & =\sqrt{\frac{2 \times 12.039 \times 670.000}{373,78}} \\
& =6.569,61 \text { karung } \approx 6.570 \text { karung }
\end{aligned}
$$

Denga Frekuensi Pemesanan 2 kali/tahun

Besarnya persediaan pengaman (safety stock) yang harus ada adalah:

$$
\begin{aligned}
\text { SS } & =(\text { Pemakaian maksimum }- \text { rata-rata }) \text { lead time } \\
& =(1.062-1.003) 3 \\
& =177 \text { karung }
\end{aligned}
$$

Penentuan titik pemesanan ulang ketika persediaan bahan baku tepung tapioka sebanyak:

$$
\begin{aligned}
\text { ROP } & =(d \times L)+S S \\
& =(33,44 \times 3)+177 \\
& =277,32 \approx 277 \text { karung }
\end{aligned}
$$

Analisa Hubungan Peramalan dan Penentuan Jumlah Produksi Optimal dengan Menggunakan Metode Program Dinamik

Perhitungan hasil peramalan permintaan untuk 12 periode yang akan datang, merupakan ketentuan jumlah produksi yang harus dipenuhi untuk setiap periodenya (tiap bulannya).

Metode program dinamik merupakan merupakan prosedur matematis yang dirancang untuk memperbaiki efisiensi perhitungan masalah yang lebih kecil. Dari perhitungan produksi dapat diambil keputusan untuk membuat rekapitulasi perencanaan produksi optimal menggunakan metode program dinamik dengan memperhatikan persediaan kapasitas permintaan dan total biaya produksi yang paling minimum. Jumlah biaya produksi optimal setiap periode dapat dilihat pada Tabel 17.
Tabel 17. Jumlah Biaya Produksi Menggunakan Perencanaan Produksi

\begin{tabular}{|c|l|c|c|}
\hline No. & $\begin{array}{c}\text { Periode } \\
\text { Produksi }\end{array}$ & $\begin{array}{c}\text { Jumlah Produksi } \\
\text { (Karton) }\end{array}$ & $\begin{array}{c}\text { Total Biaya } \\
\text { (Rp) }\end{array}$ \\
\hline 1 & Januari & 230.211 & 4.278 .931 .857 \\
\hline 2 & Februari & 239.201 & 4.446 .028 .987 \\
\hline 3 & Maret & 249.466 & 4.636 .824 .542 \\
\hline 4 & April & 261.006 & 4.851 .318 .522 \\
\hline 5 & Mei & 273.821 & 5.089 .510 .927 \\
\hline 6 & Juni & 287.911 & 5.351 .401 .757 \\
\hline 7 & Juli & 303.277 & 5.637 .009 .599 \\
\hline 8 & Agustus & 319.917 & 5.946 .297 .279 \\
\hline 9 & September & 337.832 & 6.279 .283 .384 \\
\hline 10 & Oktober & 357.023 & 6.635 .986 .501 \\
\hline 11 & November & 377.488 & 7.016 .369 .456 \\
\hline 12 & Desember & 399.229 & 7.420 .469 .423 \\
\hline & Total & $\mathbf{3 . 6 3 6 . 3 8 2}$ & $\mathbf{6 7 . 5 8 9 . 4 3 2 . 2 3 4}$ \\
\hline
\end{tabular}

Jika perusahaan tidak menggunakan sistem perencanaan produksi maka perusahaan akan mengeluarkan biaya produksi yang cukup tinggi. Berikut jumlah biaya produksi setiap periode tanpa menggunakan sistem perencanaan produksi dapat dilihat pada Tabel 18.

Tabel 18. Jumlah Biaya Produksi Tanpa Menggunakan Perencanaan Produksi

\begin{tabular}{|c|l|c|c|}
\hline No. & $\begin{array}{c}\text { Periode } \\
\text { Produksi }\end{array}$ & $\begin{array}{c}\text { Jumlah Produksi } \\
\text { (Karton) }\end{array}$ & Total Biaya (Rp) \\
\hline 1 & Januari & 263.760 & 6.312 .125 .800 \\
\hline 2 & Februari & 263.760 & 5.727 .155 .736 \\
\hline 3 & Maret & 276.320 & 6.312 .125 .800 \\
\hline 4 & April & 288.880 & 6.019 .640 .768 \\
\hline 5 & Mei & 301.440 & 6.312 .125 .800 \\
\hline 6 & Juni & 301.440 & 5.142 .185 .672 \\
\hline 7 & Juli & 314.000 & 6.604 .610 .832 \\
\hline 8 & Agustus & 326.560 & 6.312 .125 .800 \\
\hline 9 & September & 326.560 & 6.312 .125 .800 \\
\hline 10 & Oktober & 326.560 & 6.604 .610 .832 \\
\hline 11 & November & 392.500 & 6.312 .125 .800 \\
\hline 12 & Desember & 408.200 & 6.604 .610 .832 \\
\hline & Total & $\mathbf{3 . 7 8 9 . 9 8 0}$ & $\mathbf{7 4 . 5 7 5 . 5 6 9 . 4 7 2}$ \\
\hline
\end{tabular}

Sebagai tahap perbandingan apakah perusahaan mengalami penghematan biaya atau tidak jika perusahaan membuat suatu jadwal produksi. Hasil perhitungan biaya akan didapat dari persentasi tingkat efisiensi jika perusahaan menggunakan produksi dengan perencanaan.

Tingkat Efisiensi $=\frac{74.575 .569 .472-67.589 .432 .234}{74.575 .569 .472} \times 100 \%$

$$
=9,37 \%
$$

Bila perusahaan melakukan produksi tanpa perencanaan maka perusahaan akan mengeluarkan biaya yang cukup tinggi. Sedangkan jika perusahaan 
melakukan produksi dengan perencanaan yang tepat maka perusahaan akan mengalami penghematan biaya yang cukup tinggi dengan rata-rata persentase tingkat efisiensi penghematan biaya sebesar $9,37 \%$.

\section{Analisa Perbandingan Biaya Persediaan Bahan Baku Antara Kondisi Aktual Perusahaan dan Metode EOQ}

Pemakaian bahan baku pada bulan januaridesember 2019 untuk bahan baku tepung terigu yaitu 10.314.854 kg atau 412.594 karung dan bahan baku tepung tapioka yaitu $601.700 \mathrm{~kg}$ atau 12.039 karung.

Perusahaan melakukan pemesanan sebanyak 20.000 karung tepung terigu dan 600 karung tepung tapioka dengan frekuensi 48 kali pemesanan selama setahun. Berdasarkan sistem pengendalian persediaan metode EOQ, dalam menentukan jumlah pemesanan yang optimal yaitu 231.842 karung untuk bahan baku tepung terigu dengan frekuensi pemesanan 2 kali per tahun dan 6.570 karung untuk bahan baku tepung tapioka dengan frekuensi pemesanan 2 kali per tahun.

Berdasarkan metode EOQ, perusahaan harus segera melakukan pemesanan pada saat persediaan di gudang sudah mencapai tingkat 9.480 karung untuk tepung terigu dan 277 karung untuk tepung tapioka.

Berdasarkan perhitungan perusahaan diperoleh total biaya persediaan tepung terigu sebesar Rp. 38.580 .000 per tahun dan total biaya persediaan tepung tapioka per tahunnya adalah sebesar Rp. 36.660.000, Berdasarkan hasil dari perhitungan menggunakan metode EOQ maka dapat diperoleh total biaya persediaan permintaan bahan baku tepung terigu pada periode januaridesember 2019 adalah Rp. 34.125.526,65 dan total biaya persediaan permintaan bahan baku tepung tapioka pada periode januari-desember 2019 adalah Rp. 32.208.474,88.

\section{Kesimpulan}

Adapun kesimpulan yang didapatkan daripada penelitian yang dilakukan yaitu sebagai berikut :

1. Perencanaan produksi dengan memperhatikan total biaya produksi dan biaya persediaan yang paling minimum diperolah hasil perhitungan biaya dengan perencanaan menggunakan program dinamis sebesar 67.589.432.234 selama satu tahun dan biaya tanpa perencanaan sebesar 74.575.569.472 selama satu tahun. Perusahaan akan mengalami penghematan biaya yang cukup tinggi jika perusahaan menggunakan sistem perencanaan produksi pada setiap periodenya. Persentase tingkat efisiensi penghematan biaya yang diperoleh oleh pihak perusahaan jika perusahaan menerapkan sistem perencanaan produksi sebesar $9,37 \%$.

2. Pengendalian persediaan dengan metode EOQ, jumlah pemesanan bahan baku yang optimal pada bahan baku tepung terigu adalah 231.842 karung (frekuensi pemesanan 2 kali per tahun) dan segera melakukan pemesanan pada saat persediaan di gudang sudah mencapai tingkat 9.480 karung. Sedangkan jumlah pemesanan yang optimal pada bahan baku tepung tapioka adalah 6.570 karung (frekuensi pemesanan 2 kali per tahun) dan segera melakukan pemesanan pada saat persediaan di gudang sudah mencapai tingkat 277 karung untuk tepung tapioka.

\section{Daftar Pustaka}

[1] M. I. Siregar, C. I. Erliana, and Syarifuddin, “Pengukuran Reliabilitas Kerja Manusia Menggunakan Metode SHERPA dan HEART pada Operator CV. Diwana Sanjaya," SNTI, 2019.

[2] N. Emmiyati, M. A. Rasyid, M. Asfah Rahman, A. Arsyad, and G. D. Dirawan, "Multiple intelligences profiles of junior secondary school students in Indonesia," Int. Educ. Stud., 2014, doi: 10.5539/ies.v7n11p103.

[3] A. Ahyari, "Pengendalian Produksi II," Yogayakarta BPFE UGM, 1990.

[4] yudhistiar maulana, "PENGARUH LUAS LAHAN, JUMLAH PRODUKSI DAN HARGA TANDAN BUAH SEGAR (TBS) KELAPA SAWIT TERHADAP NILAI PDRB SUB SEKTOR TANAMAN PERKEBUNAN DI KALIMANTAN BARAT," J. Curvanomic, 2019.

[5] P. Denny Sentia, D. Asmadi, and D. Ramadhan, “Pengendalian Persediaan Suku Cadang Mobil Menggunakan Pendekatan Inventori Probabilistik (Studi Kasus PT. XYZ)," in SEMINAR NASIONAL TEKNIK INDUSTRI UNIVERSITAS GADJAH MADA 2016, 2016.

[6] A. Ahyari, "Manajemen Produksi, Pengendalian Produksi.," Yogyakarta: BPEE. 2006.

[7] C. R. Sandro Putra, "Perencanaan Pembangkit Listrik Tenaga Surya Secara Mandiri Untuk Rumah Tinggal," Semin. Nas. Cendekiawan, 2016.

[8] E. Wahyuni, D. Iranata, B. Suswanto, C. B. Nurcahyo, and W. Sutrisno, "Assessment of Vulnerable Buildings Due to Earthquake Loading Using Rapid Visual Screening Smartphone Application," Int. J. Adv. Sci. Eng. Inf. Technol., 2018, doi: 10.18517/ijaseit.8.2.4336.

[9] M. I. Perangin-angin, A. H. Lubis, I. S. Dumayanti, R. B. Ginting, A. Putera, and U. Siahaan, "Implementation of Fuzzy Tsukamoto Algorithm in Determining Work Feasibility," IOSR J. Comput. Eng., 2017, doi: 10.9790/06611904045255.

[10] L. Sumayang, "Dasar-Dasar Manajemen Produksi dan Operasi," Jakarta: Salemba Empat, 2003.

[11] Amri, Trisna, and E. N. Harahap, "Perencanaan Pengendalian Produksi Air Minum Dalam 
Kemasan Menggunakan Metode Aggregate Planning," Malikussaleh Ind. Eng. J., 2012.

[12] P. Utomo and F. W. Prayitno, "Perancangan Dashboard Sistem Informasi Untuk Agile Manajemen Proyek dengan Menggunakan JIRA (Studi Kasus: di PT. FLASHiZ Indonesia)," Sisfotek Glob., 2015.

[13] M. Saiful, A. Rapi, and W. Flannery, "Penjadwalan Produksi Dengan Metode Branch and Bound Pada Pt. Xyz," Bksti, 2014.

[14] D. Abdullah et al., "A Slack-Based Measures within Group Common Benchmarking using DEA for Improving the Efficiency Performance of Departments in Universitas Malikussaleh," MATEC Web Conf., 2018, doi: 10.1051/matecconf/201819716005.

[15] C. E. Widodo, “Optimasi Penjadwalan Mesin Produksi dengan Menggunakan Metode Campbell Dudek Smith (cds) pada Perusahaan Manufaktur," Univ. Negeri Yogyakarta, 2014.

[16] dan M. S. Wibisono, Setyawan, "Sistem Informasi Manajemen Puskesmas (Simpuskesmas) berbasis Cloud Computing," Teknol. Inf. Din., 2012. 